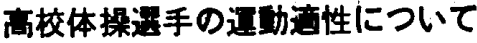

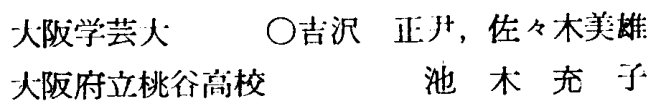

目的 体操選手の体力は淌校时代にとの基礎が形成さ れるといら前提のもとに亩校体操選手の形態及び運動能 力面の諸測造を行ない，その身体的特徽を把据すること によつて，休操選手の身体適性を明らかにしようとし た。

方法 昭和 40 多: 5 月上旬，11 万小旬の 2 回にわたり 㘳女部 61 名の高校休操選手を刘象とし，14 項目（身長， 体重，胸明，座俕，湖活量，握力，背筋力，舫直とび，

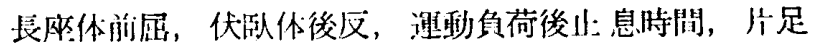
站，壮足爪先汒ち，サイドステップ，仰臥休扰こし）の

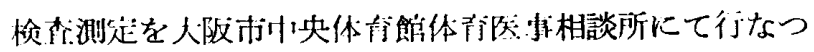
た。 その他同所にて受検した数種円のスポーツ選手男女 計 760 名を抽出し，休操選手との比較を行なつた。

結論 以上の資料を整理检䣓した結果から次のような 諸器が休操選手の体格们，体力物特としてあげられよ 5 .

1. 形態的には小挝である（自己の体和を领荷として

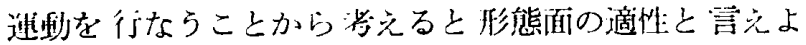

う.)

2. 管力は全般似に与ぐれ，けでも笚位体重当りの能 נルは他のスポーツ部員に比べかなり高い值を示す. 特に 尖子の据力の $0.658 \mathrm{~kg}$, 然于の背箭力口 $2.866 \mathrm{~kg}$ がす ぐれている。

3. 呼吸循環㙨能は他のスポーツ部員よりもはるかに 少り，また競技力との相関むまつたく見られなかつた。

4. 平㫿性は女子に扣いて，他のスポーツ部負に此べ 特にすぐれた平均値を示している。

5. 柔㳄性は特にすぐれ，中でも体解屈は，女子に至 つては $0 \mathrm{~cm}$ を示すことが必要条件であると言えよ5。 体後反も菭い值を小すことから必要ではあるが，競技力 との相開は余り見られなかつた。

6. 敏捷性はは特にめ芯つたところはない.

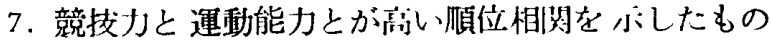
に据力，背笳力，垂直とび，休前屈，片足爪先立ち，サ イドステップ, 体起こし, 握力指数, 背箭力指数などが

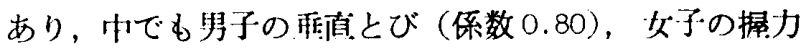
(0.82)，体起こし $(0.77)$ ，搌力指数 (0.86) なとに特 に间い相削が見られてた。

\section{スポーツテストに於ける診断テストと運動能カテス トとの相関関俰}

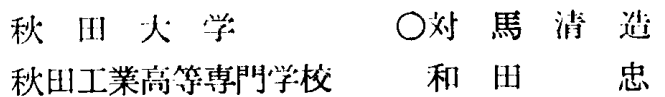

粕言 スポーツテストが盛んになることは，日常生活 に於ける煡康稚持つため，又基礎的身体能力を試す機会 として有効なものと考える，今回はテストの活用の一環 として体力診断テスト（背笳力）と，運動能力（走・ 跳・投・慜垂・持久走）との相関関係を秋田県内小・ 中・高生（男 334 名，女 337 名）について（任意抽出法 による) 調查検討した。

成转检討 男子背筇力と $50 \mathrm{~m}$ 走・走巾跳・ハンドボ 一ル投との相関は小・中・高共に 1\% $5 \%$ 以下の危険

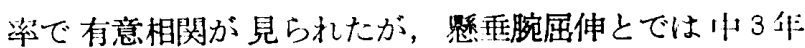
に相閶が兒られたのみである，持久走とでは中学尘に $1 \%$ 以下゙の危険率で明かな相関関係が見られした。このこ とは背筋力が增強するに伴つて持久走も発達することを 意味するものであるが，これが茼校に進もに従つてその 阅係が見られないことは高校 2〜3 年の年令頃では身体 発夺がある程传固定することに时来するものと思考され た，女子に於いては $50 \mathrm{~m}$ 走に小・中校生がその有意性
が見られるが，高校生では全く相関が見られなない。これ は女子特有の生理的身休発育即ち，女子は豕年的に重心 が下腿部に降下するため脚力の強さは有しても，敏捷性 が火ける事もあると思わ机る，走巾跳に於いては高 3 年 に認められない外はすべて相闺に有意性を見た。ハンド ボール投・鬃垂には，小・中・高すへて相関が見られた が，持久走に於いては殆んど相閔に有惫性が見られてか つた.

要約 (1) 背朌ノと $50 \mathrm{~m}$ 走・走巾跳・ハンドボール投 には小〜高共 $\mathrm{P}<0.01 \sim \mathrm{P}<0.05$ で有意相関が見られ た。曔垂とではけいに $\mathbf{P}<0.01$ の関係を見たのみで外 は全く無相関に近いものも小された。（2) 持久走では中 兴生に $\mathrm{P}<0.01$ で离校には低い数值のみ見られ相関が 見られなかつた。 (3) 女与では 50m 走に小・肪夫々 $\mathrm{P}<0.01 \sim \mathrm{P}<0.05$ で相獜に有意性が見られたが，间 校に於ては殄儿ど相関が見られてない（4) 走巾跳・ハン ドボール投には $\mathrm{P}<0.01 \sim \mathrm{P}<0.05$ の相関に有意性が 見られたが，榡重では小学生に有意相関が見られず， 中・高生に夫尖有意な関係が見られた。（5) 持久性には 打・高校共食く相関に有意性を見なかつた。 